\title{
The Region and Regional Problems through the Eyes of Young Students: Social Historical Memory
}

\author{
Eduard S. Demidenko* \\ Vladimir V. Krivosheev \\ Immanuel Kant Baltic Federal University, Russian Federation \\ *Corresponding Email: demidenkoes@mail.ru
}

\section{Doi:10.5901/mjss.2015.v6n6s7p161}

\begin{abstract}
The article presents the analysis of sociological research on humanitarian students of Kaliningrad higher educational institutions. The emphasis is made on the young students' historical consciousness development, and on the existence of their historical memory. The author relates current methodological provisions to the adjustments necessary due to the character of sociological researches on youth.
\end{abstract}

Keywords: region, regional identity, historical consciousness, historical memory

\section{Introduction}

Prior to presenting the program, its methods and results, it is conceived expedient to dwell on three important in our opinion methodological aspects. We are referring, firstly, to the rationale for selecting young people as a research object, secondly, to the necessity to concentrate on local micro-sociological objects of study on historical consciousness in this social category; finally, to the basic provisions determining the selection of methods of sociological analyses on historical consciousness.

Here is the rationale for selecting young people, specifically students, as a research object. It may be said that youth is a vital social category; i.e. the consciousness maturity of this part of a society is significant if not to say deterministic for its future success, progress and prosperity, or, on the contrary, for its failures, mistakes and delusions. Unfortunately, the latter is also possible: the society may lose its positive development impulses and degrade, unless modern youth learns to combine the best traits of previous generations with the potential for innovations, which is characteristic of the new generation. One would consider this trivial reasoning unnecessary. Hardly any researcher or even a layman would argue the obvious fact that the future belongs to the young, and that they inevitably will take place of the gradually disappearing older generations. The seeming lack of prospects of any meditations on this issue should not discourage the attempt to understand the core of the problem. That is the studies of young people's willingness to fit into a society, to share common traits and values as well as to cherish traditions, customs, historical memory of the older generations. This appears to be of greater importance since the unity and integrity of a social world do not preclude the great variety of its elements. Thus, we deem it important to focus on young people of all the social categories.

It can be added that sociological studies of youth, and thus formation and development of the sociology of youth have deep-rooted traditions. One can invoke the studies of such foreign researchers as S. Eisenstadt (1956) and S. Frith (1984). Russian sociological studies of the young generation have also accumulated vast experience. V. Lisovskiy (1990), I. Kon (1973), as well as many other sociologists and social psychologists significantly contributed to this region of science.

Here are few comments regarding the statement that microsociology is the most relevant direction of sociological analyses. In our viewpoint it is fair to state that "modern sociology has embraced the period of humanization, reorientation from rational knowledge of global issues towards knowledge and understanding of local communities, minorities' distinctiveness and people's everyday social practice; from macro- to microanalyses of social processes" (Yadov, 2007, p. 257). Therefore, it is important for sociologists to focus on everyday practices, behavior, social interaction, individual and small group perspectives alongside global and national scale studies. On the one hand, this provides for determining the continuation of studies of society, its structures and spheres. On the other hand, this gives an insight to fundamental qualities of consciousness of individuals included through smaller entities into a complex and peculiar society. Therefore, 
the research conducted qualifies as micro sociological one.

Another methodological aspect is related to the study of historical consciousness and historical memory.

It is commonly known that historical memory being a part of social consciousness includes knowledge, values, stereotypes etc. that provide for social stability and intergenerational continuity. That is why sociological analyses of various aspects of historical consciousness functioning seems to be the most relevant objective. Toschenko (2000 p.15) reasonably, in our opinion, notes that "unlike philosophy, sociology does not study theoretical or even everyday social consciousness, but analyzes real functioning consciousness expressed by the actions (principals) of particular individuals".

As sociologists seek information from people, they face the fact that every single research object whether it is a person, a group, a stratum or a cohort presents a strange combination of some scientific and common (non-scientific) ideas of history as a whole, history of Russia, history of the nation, as well as history of his/her/their city, village, or even family. The most frequent subjects in focus are major historical events affecting the country, social classes and groups, individuals, or some national problems. (Toschenko, 2000 p.16). K. Manheim (1994) pointed out the significance of historical memory and the role of the past for personality formation. Describing the place of youth in a society, he emphasized that "history lessons for youth" were recognition of historical tradition making the conduction of social changes possible (Manheim, 1994 p. 447). Manheim highlights the influence of historical consciousness on social energy of youth, and the necessity for fundamental historical education for the young. One of the specifics of historical consciousness in Russia is that it sometimes incorporates opposite elements, contradictory opinions, conflicting ideas. That stands to a reason. Gorshkov and Sheregi $(2010,197)$ note, "Most of the currently living generations in Russia have socialized under considerably differing political conditions (I.V. Stalin's dictatorship, N. Khrushchev's 'thaw period', 'stagnation' under L. Brezhnev, 'demise' of the superpower under M. Gorbachev, B. Yeltsin's 'shock therapy')". That is why new political system standards, social relations and values should not just be formed but they should substitute the majority of previous ones. This has an impact on the formation of historical consciousness in a generation undergoing socialization" (Gorshkov, Sheregi, 2010).

\section{Scope and Course of Study on Historical Consciousness of Young Students}

Historical memory involves historical development of both society as a whole and its separate units, e.g. territory-based social communities. Therefore, social consciousness phenomenon can be both common, and local.

It is a known fact, that the Kaliningrad region was created on 1/3 of Eastern Prussian territory (Poland ceded the remaining 2/3) after the victory in the Great Patriotic War. In order to find the level of knowledge of the Kaliningrad region history, the attitude towards this land's past, towards the people who put it on the map the author questioned 178 humanitarian students of Kaliningrad higher educational institutions (Kaliningrad branch of Moscow University of Finance and Law and Kaliningrad branch of Moscow International University) in April-May, 2015. Among the respondents, there were psychologists-, lawyers- and managers-to-be. Due to general considerations no historians-to-be were questioned. Random sampling was used. The survey was conducted in the form of a questionnaire.

The questionnaire was specifically designed, firstly, to reveal the knowledge of some historical events and facts of both pre-Soviet period and recent past of the Kaliningrad region; secondly, to identify the attitude of the region's young citizens towards these events; thirdly, to elicit the students' knowledge of the famous people whose life and work were tightly linked to this land regardless of the period they lived in.

First, it is important to emphasize that the students' self-evaluation showed quite a high rate of interest in the region's past. $61.7 \%$ claim to be interested in Prussian, German, Soviet and current stages of its history. Large number of the respondents $(18.3 \%)$ pointed out that they are interested only in pre-war times. Presumably, this high rating is the result of re-enactments for many historical events (for instance, the Battle of Preussisch-Eylau of 1807, the Battle of Gumbinnen of 1914) and of reasonably effective conservation of historic landmarks, old residence and religious buildings and structures. A continuing discussion on the city center restoration (so called "Heart of the city" project) should also be mentioned.

Still, there is a significant number (14.2\%) of those who chose "not interested at all" answer. Although the interest to the region's history seems to be considerable and there is a course of "History of Russian West" taught in secondary school, the survey revealed insufficient knowledge of facts and events of the past. It is well known that from 1758 until 1762 during the Seven Years' war Eastern Prussia was actually a part of the Russian Empire. In German historiography, this period is referred to as "the first Russian period" (Zotov, 2014). It turned out that less than a half of the respondents $(43.6 \%)$ are aware of this fact.

The survey also revealed that the students know little about the outcomes of the Great Patriotic War and 
Konigsberg renaming. A considerable number of the respondents (about 28\%) assume that the destiny of Eastern Prussia was determined not during Berlin (Potsdam) Conference in 1945, but during other international forums including, for instance, the final meeting of Conference for security and cooperation held in Helsinki in 1975. There was also a confusion about the Big Three's Potsdam decision on the Eastern Prussian territory. $32 \%$ of the respondents believe that the entire territory of Eastern Prussia was ceded to the Soviet Union. $24,5 \%$ think it was divided by the USSR, Poland and German Democratic Republic. $9 \%$ are confident that Eastern Prussia was integrated into the USSR and GDR. Only one third of students (35\%) knows that one third of the territory became a part of the USSR, and two thirds became a part of Poland. There was also confusion with the year of Konigsberg and its area had been renamed into Kaliningrad and the Kaliningrad region correspondingly. Only half of the respondents (49.3\%) managed to state the correct year - 1946 .

So, why did Konigsberg become Kaliningrad? Why was it named after "the All-Union Headman", one of the USSR leaders, M. Kalinin? $42.4 \%$ of the respondents chose sort of bureaucratic answer. In their opinion, it was Kalinin who sent a reconstruction commission to the city. $26 \%$ assume the city was renamed the same year he was reelected as a Chairman of the Presidium of the Supreme Soviet of the USSR. $27.2 \%$ gave a correct answer that it happened only because Kalinin died in 1946.

There were questions related to Eastern-Prussian operation of the Soviet forces and the storm of Konigsberg. 55.6 $\%$ students correctly named the commander who ran the storm. It was Marshal of the Soviet Union A. Vasilevsky. But, there were also some other answers to this question: G. Zhukov (18.4\%), I. Cherniahovsky (21\%), K. Galitskiy (4.1\%).

The students showed poor understanding of destiny of German residents of the area after the war. $43.1 \%$ of the respondents think that part of the Germans remained on the territory of the region and subsequently merged into Soviet population. $5.8 \%$ of the respondents believe that the Germans were taken inland of the USSR. Only less than half of the respondents (48.7\%) know that all the Germans were repatriated.

There is one more interesting thing related to the war worth mentioning. The monument to 1200 guardsmen in Kaliningrad, the first large construction of this type on the territory of the country, was opened as early as in September of 1945. This memorial has a plaque with the opening date and the names of the monument's architect and sculptor. On 9 May, almost all the citizens come to the monument to honor fallen soldiers. This public tradition has been set up back in the Soviet period. Only $12.4 \%$ respondents managed to state correctly the year it was unveiled. The majority (44.7\%) supposes it happened in 1950. Presumably, the idea that any event in our homeland shall coincide with an anniversary regardless of its importance has become ingrained into even young peoples' minds.

When it comes to the people who celebrated this land, an iconic figure of Immanuel Kant cannot be overlooked. He is a prominent symbol of the land. Presumably, while lecturing on the ideas of this great citizen of Konigsberg philosophy teachers do not forget to tell their students about his biography. Over $75 \%$ respondents learned well that he had been born here and had spent his entire life here. Although there is quite a number (almost 13\%) of those who think he spent only his last years in Konigsberg, and $8 \%$ are of opinion that after his death his ashes were brought here from another Eastern Prussian city.

Here are the results of the famous Soviet citizens ranking. A songwriter and a pop singer O. Gazmanov (who studied and lived in Kaliningrad for some time) won 73 votes, and cosmonaut A. Leonov who made the first spacewalk in history (he also studied and lived in Kaliningrad for some time) won 48 votes. Well. There is not much to say. Every generation choses its own heroes.

Contrarily to the believe of some local politicians that advocate for the return of city's previous name, the students do not support this idea. $72.4 \%$ think that the city should not be called Konigsberg again. Their basic argument is that the city should have Russian name. Some of the advocates for the historical name of the city $(22.8 \%$ of the total number of the respondents) used historical-philosophical reason ("history is history"), others express their strictly ideological position ("Kalinin is not the person whose name should be immortalized").

\section{Conclusion}

In our opinion, the conducted research leads us to the following conclusions. First, a considerable part of young students believes that they are interested in the local history, i.e. the history of their region. Secondly, it is stated on reasonable grounds that the students have no more than a belief in such an interest, as the survey revealed crucial gaps in the knowledge of supposedly common facts of the region's history. Therefore, the young people do not see the correlation between the history and the current problems in the region. Taking all things together, we can conclude that the young people's desire to know at least something about the past of the Kaliningrad land should be welcomed. However, the humanitarian students' knowledge of the local history is still fragmentary and superficial, and this inevitably influences 
historical consciousness as a whole. Development of historical memory of the young students, unfortunately, is not a smooth process, and this naturally affects the attitude towards events and artifacts of the remote and recent past.

\section{References}

Eisenstadt, S. (1956). From generation to generation, Glencoe.

Frith, S. (1984). The Sociology of Youth. London: Open University Press.

Gorshkov, M.K., \& Sheregi, F.E. (2010). Historical consciousness of youth. Science and society: Vestnik Journal of the Russian Academy of Sciences, 80 (3), 195-203.

Kon, I.S. (1973). Adolescence as a social problem. Society and youth. Ed. 2, revised and enlarged Coll. V.D. Kobetskiy. Moscow.

Lisovskiy, V.T. (1969). Portrait sketch: life projects, interests and aspirations of Soviet youth. M.

Lisovsky, V.T. (1990). Soviet students. Sociological sketches. Moscow: Vyshaya shkola Publ.

Manheim, K (1994). Man and society in an age of reconstruction. Manheim K. Diagnosis of our time. M.

Toschenko, Zh.T. (2000). Historical consciousness and historical memory. Current state analyses. Recent and contemporary history, № 4.

Yadov, V.A. (2007). Strategy of sociological research. Description, explanation, understanding of Soviet reality. 3-rd ed., corr. Moscow. Zotov, S. (2014). What happened to Eastern Prussia? (Online) Available: http://russian7.ru/2014/09/ (December 19, 2014). 